\title{
Studying and improving intermediate rail fastening of rail transport
}

\author{
Volodymyr Hovorukha ${ }^{1, *}$ \\ ${ }^{1}$ Institute of Geotechnical Mechanics named by N. Poljakov of National Academy of Sciences of \\ Ukraine, 49005, Dnipro, Simferopolska Str., 2a, Ukraine
}

\begin{abstract}
Topical problem concerning the improvement of intermediate rail fastening of a railway track of railroad transport as well as industrial and underground rail one has been considered taking into account peculiarities of operation in terms of curved sections of a route with smallradius curvature. Objective of the paper is to improve operational parameters of a railway track with extra small curvature radii in terms of railroad gauge adjustment. Operation of the components of intermediate rail fastening, being subject to intense wear and destruction due to the effect of great transverse and horizontal loading within the curved route sections with small-radius curvature, has been and analysed. Innovative engineering solutions to improve intermediate rail fastening have been proposed. Such peculiarity of the device of intermediate rail fastening provides increased durability and working capacity of rail fastening components in terms of considerable transverse loading within the route sections with small-radius curvature. The obtained results may be applied for underground and industrial rail transport as well as for railroad one.
\end{abstract}

\section{Introduction}

One of numerous tasks, which rail transport of various industries faces (in particular, mining enterprises and railroad transport), is the improvement of technical level of railroad structures including intermediate rail fastening. Intermediate rail fastening is the most important part of the upper structure of a railroad determining dynamic indices of the interaction with a rolling stock, reliability, operating capacity, and cost during the construction as well as different expenditures in the process of the whole operating cycle. The problem is quite topical for all the railroads worldwide.

Main functions of the fastening are as follows: reliable connection of rails and rail seat base, electrical insulation of the rail length within the areas with automatic block signaling and electric traction, and reduction of loading and vibration transferred from the rails to sleepers and under-sleeper base, especially within the curved route sections with smallradius curvature as well as during high train velocities and intense traffic flows.

To solve the problem, thousands of patented structures of intermediate rail fastening have been developed. Such countries as Germany, Great Britain, Russia, France, Ukraine and others are leading ones in this field.

Corresponding author: igtm.rail.trans@gmail.com 
Well-known papers [1-11] represent theoretical, experimental, and operational studies as for developing and improving intermediate rail fastening, determining its technical characteristics and indices as well as providing their scientific and technical potential in the development of track facilities of the railroad transport. Nevertheless, there is still a set of complex and unsolved problems concerning elaboration of intermediate rail fastening which provide longer operational life and improved reliability and durability of the structural components especially in terms of curved sections of a route with small-radius curvature characterized by high velocities and intense traffic flow.

Objective of the study is to determine stress-strain state of basic components of intermediate rail fastening and to improve their design for the railroad with small-radius curvature.

\section{Methodology}

Stress-strain state of basic components of intermediate rail fastening has been analyzed with the help of a well-known finite element method. Determination of both rational geometry and parameters of elastomeric pad riffles and geometry of elastic clamps providing the required indices of stress, elasticity, and performability is the specific feature of the study. Comparative analysis of the operation of those structural components has involved analogues of the products being either series-produced or under experimentalindustrial testing.

Brief analysis of technical condition of intermediate rail fastening has demonstrated that in terms of curved sections of a route with small-radius curvature, components of intermediate rail fastening are subject to intense wear and destruction due to the effect of considerable transverse and vertical loading. In this context, transverse loading within the straight-line railroad sections is $30-60 \mathrm{kN}$ while in terms of curved ones, it is $80-160 \mathrm{kN}$ [1-6] if there are inclinations of main line up to $30 \%$. Vertical and transverse loading are of considerable importance on rail tracks of industrial transport within the curved sections [11] owing to the use of locomotive units with static vertical loading (2560-3600 kN), selfpropelled dump cars (550-670 kN [12]), and railroad inclinations up to $60 \%$. As for railroad of underground rail transport, vertical loading may reach $60-120 \mathrm{kN}$ and transverse ones may demonstrate values of $20-45 \mathrm{kN}$ [10].

Efficient operating capacity of rails for railway, industrial, and underground rail transport involves numerous structures of intermediate rail fastening. The most up-to-date fastening systems are used for railway transport. Fasteners of imperfect design are used for rail transport at industrial enterprises and for underground railroads.

In terms of curved sections of railroad transport with small-radius curvature being 200-600 $\mathrm{m}$ and less, intermediate rail fastening with railroad gauge adjustment is used; in particular, value of gauge width is changed up to $20-25 \mathrm{~mm}$ according to the curvature parameters and railroad design. Such types as KPP-5K, SKD-65B (Ukraine), SKD-65B, SKD-65D, ZHRB-65, ARS-4K (Russia), Vossloh System W300 (308) (Germany) [1-11] and others are the most popular structures of intermediate rail fastening with railroad gauge adjustment.

Fastening of KPP-5K type helps adjust gauge width within the curved section of a route with the radius being more than $200 \mathrm{~m}$ with possible gauge widening within the range of 1520-1536 mm. To adjust the gauge width, special rectangular plugs are used; the plugs have different thickness of side walls as well as internal opening to go through the anchor head and operating position devices. Gauge width is adjusted by means of step-like remounting of a rectangular plug around the axis of an anchor head. Thus, structurally, gauge width is adjusted by mounting the element of a rectangular plug with different width between the side part of a rail base and stopper part of an anchor head. 
Structure of intermediate rail fastening of SKD-65B type makes it possible to adjust rail gauge as for the curve radii being more than $200 \mathrm{~m}$ by mounting adjustment cards of various width placed vertically between lateral edges of the rail foot and rim collars of a baseplate.

Popular structures of intermediate rail fastening of ARS-4K, ZHRB-65, Vossloh System W300 (308) and other types have similar engineering solutions as for the devices to adjust gauge width for curved sections with small-radius curvatures.

\section{Results and discussion}

The paper represents detailed original studies of the railway facilities with the use of innovative structural engineering solutions of intermediate rail fastening. Stress-strain state of basic components of the innovative fastening structure in terms of geometry and parameters of elastomeric pads and elastic clamps has been determined.

Such engineering solutions increase durability and operational reliability of the intermediate rail fastening under conditions of considerable dynamic track loading within the curved sections with small-radius curvature for railway as well as industrial, and underground rail transport. All the engineering solutions are copyrighted [12-16].

While studying stress-strain state of intermediate rail fastening and its components, well-known methods of mechanics with certain assumptions have been applied including a separation method when structural components and their interaction with other elements of the system are analyzed with the help of simplified model where interaction of other structural components is considered by means of simpler dependences obtained with the help of other models stipulated in further research.

Main condition of the simplified studies is the preservation of their strength, elasticity, and further performability since they should not experience destruction in terms of standard and maximum loading during the operation. Owing to that fact, strength and durability of the fastening components are evaluated according to computational models and finite element model (FEM) involving specialized design and computing systems [17-18].

Computational models have been developed for each component of intermediate rail fastening. Studies are aimed at determining displacements and stresses in finite elements as well as in the structure elements due to the effect of standard and maximum loads.

To evaluate strength indices of the structural components operating under conditions of complicated stress state characterized by main stresses within a risk point $\sigma_{1}, \sigma_{2}$, and $\sigma_{3}(\mathrm{MPa})$, a hypothesis of strength theory has been applied. The hypothesis stipulates possibility of comparison of some equivalent stress $\sigma_{e}$ and intense stress $\sigma_{i}$ with the maximum strength for the studied material of the fastening structure component $\sigma_{o}$, which corresponds to a simple uniaxial tension (compression). Conditions characterizing nonavailability of limit state in the structural component material are represented as follows:

$$
\sigma_{e}=f\left(\sigma_{1}, \sigma_{2}, \sigma_{3}, k_{1} \ldots k_{n}\right) \leq \sigma_{o}
$$

where $k_{1}, \ldots k_{n}$ are some constants depending upon the strength theory being used.

The studies involved a theory of octahedral tangential stresses or specific potential distortion energy to evaluate strength of elastoplastic materials; the theory meets the test of experiments well. According to that theory, $\sigma_{e}$ is found from the known ratio: 


$$
\sigma_{e}=\sigma_{i}=\left\{\frac{1}{2}\left[\left(\sigma_{1}-\sigma_{2}\right)^{2}+\left(\sigma_{2}-\sigma_{3}\right)^{2}+\left(\sigma_{3}-\sigma_{1}\right)^{2}\right]\right\}^{\frac{1}{2}}
$$

In this context, strength condition may be determined according to expression:

$$
\sigma_{e} \leq[\sigma]
$$

where $[\sigma]$ is admissible stresses for the material of the structural components under consideration.

To analyze stress-strain state of elastomeric rail pads, contact stresses on their surfaces from the rail foot and rail seat base (sleeper, lining) as well as in deep part of elastomeric pads, two characteristic structures have been considered: series elastomeric pads with sinusoidal riffles, shown in Figure 1, $a$ corresponding to patent [19], and trapezoidal riffles, demonstrated in Figure 1, $b$ and Figure 4 corresponding to patent [15] etc.

Figure 1, $c, d$ shows actual strength characteristics of elastomeric pads with sinusoidal and trapezoidal shapes of riffles obtained in terms of experimental studies of series and experimental samples of the studied batches of manufacturing plants. Stress was applied and removed from the pads by means of loads from $0.0 \mathrm{kN}$ up to $200.0 \mathrm{kN}$. Sinusoidal pads are made of thermoplastic polyurethane of Vitur T-1413-85 grade according to TU 6-05-221-526-85. Trapezoidal pads are made of thermoplastic polyurethane of LARIPUR 9020 grade. Stiffness characteristics for the material are taken with $E=55.0 \mathrm{MPa}$ modulus of elasticity and $v=0.45$ Poisson ratio.

Analysis of the studies represented in Figure 1,e,f demonstrates that both pad types are characterized by significant elastic deformation while applying and removing stress from the samples. In this context, being loaded up to $100.0 \mathrm{kN}$, pads with sinusoidal and trapezoidal riffles demonstrate elastic deformation values of $4.62 \mathrm{~mm}$ and $2.71 \mathrm{~mm}$ respectively; if load is $200.0 \mathrm{kN}$, the values will be $6.0 \mathrm{~mm}$ and $5.0 \mathrm{~mm}$ respectively.

Deformation value of pads with sinusoidal riffles is more than the deformation value of trapezoidal pads by 1.7 times in terms of loading up to $100.0 \mathrm{kN}$; if loading is up to $200.0 \mathrm{kN}$, the value will be higher by 1.2 times. Reason of increased deformation of pads with sinusoidal riffles comparing to trapezoidal ones is in the increased deformability of the tops of sinusoidal riffles in terms of minor value of contact surface and conic shape of the riffles bodies.

Those tops develop increased deformability in the initial loading stage, by 1.5-2.0 times higher comparing to the trapezoidal riffle geometry. Further, such geometry of the top with sinusoidal riffles will result in increased stresses and wear [20].

Considered dependences of elasticity are characterized by non-linearity since the pads are made of elastomeric materials in the form of polyurethane. Moreover, there is certain geometrical non-linearity caused by the available variables of geometrical parameters of riffles as well as nonlinear pads deformability due to loading.

The problem was solved using finite element method $[17,18]$.

Figure 2, $a, b$ represents general view of a pad with trapezoidal riffles and finite-element computational scheme of a pad.

While designing a pad, three-body contact problem was solved: rigid rail foot, elastic pad, and rigid pad (or ferroconcrete sleeper). Friction coefficient between a pad and adjacent rigid elements were taken as equal to 0.5 .

First, boundary conditions and then diagram of pad loading deformations obtained experimentally (Fig. 1, $f$ ) have been selected as the priorities while solving the problem.

Pad was loaded in a stage-by-stage way due to its nonlinear rigid characteristics. Value of elasticity modulus was specified during the calculation taking into account diagrams of pad compression. 


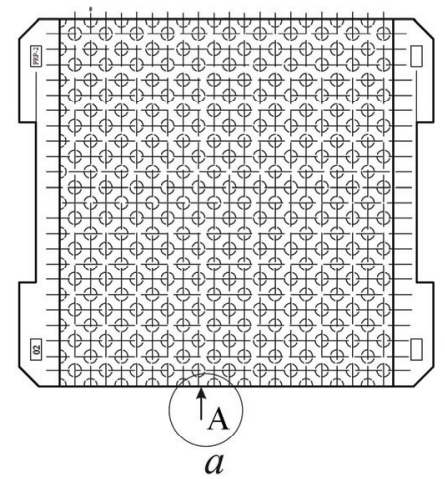

Unit A
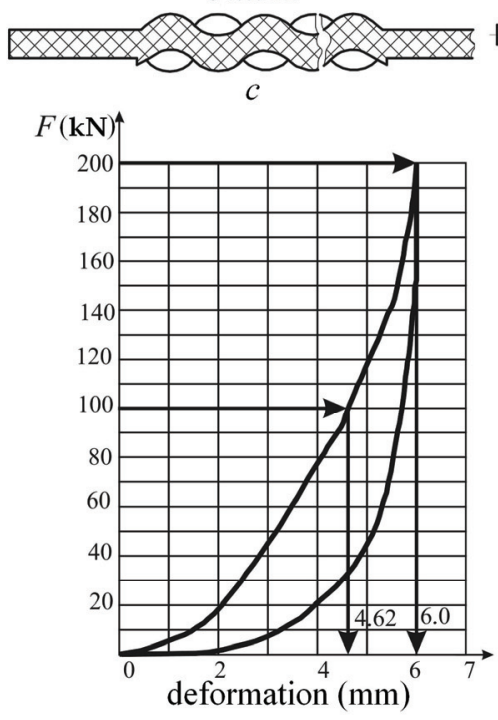

e

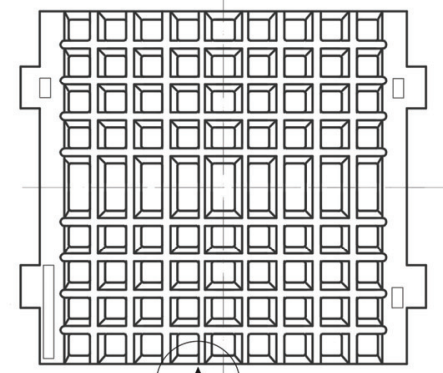

( ${ }^{\mathrm{B}}$

$b$

Unit B
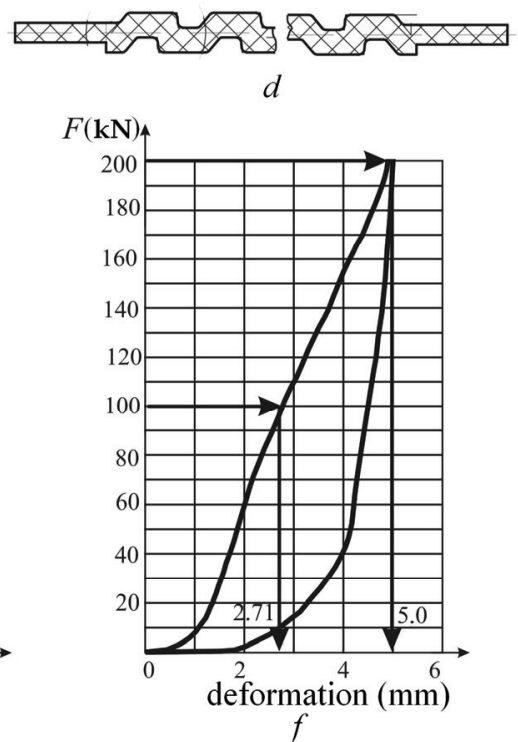

Fig. 1. Elastomeric pads with sinusoidal (views $a$ and $c$ ) and trapezoidal (views $b$ and $d$ ) shapes of riffles: $a, b$ - top view; $c, d$ - front view; $e, f$ - physical characteristic of sinusoidal and trapezoidal pads.

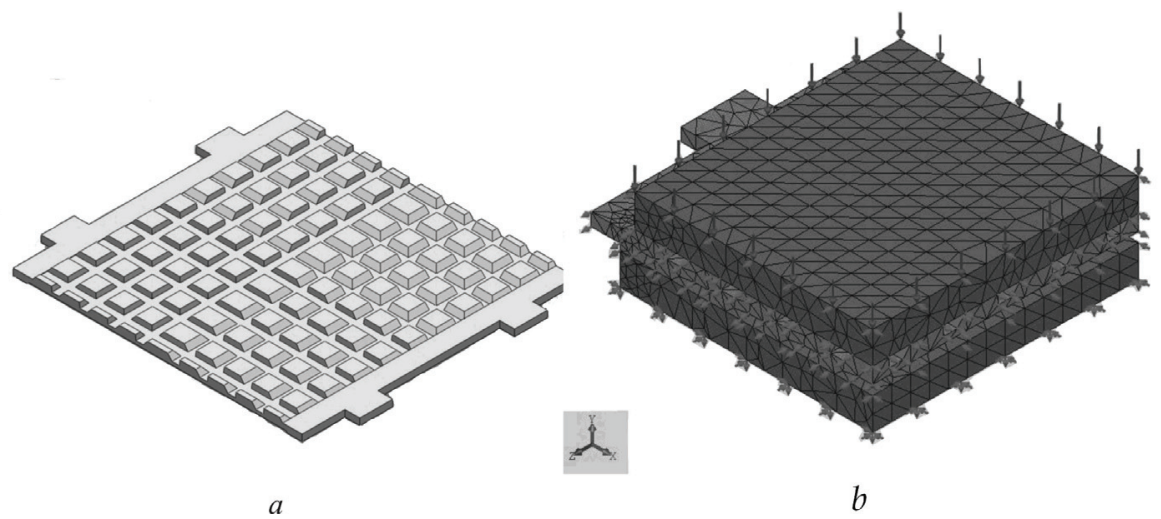

Fig. 2. Pad with trapezoidal riffles $(a)$ and its finite-elements computational scheme $(b)$. 
Figure 3 represents geometry of pads in terms of deformation (Fig. 3, $a, b$ ), after $100.0 \mathrm{kN}$ loading (Fig. 3, c, d) and after $200.0 \mathrm{kN}$ loading (Fig. 3, e, f). Moreover, the figures demonstrate fields of absolute vertical (UY) (Fig. 3, c,e) and horizontal $(U X)$ (Fig. 3, $d, f$ ) deformations ( $\mathrm{mm}$ ) of a pad compressed between the rail foot and lining (or sleeper).
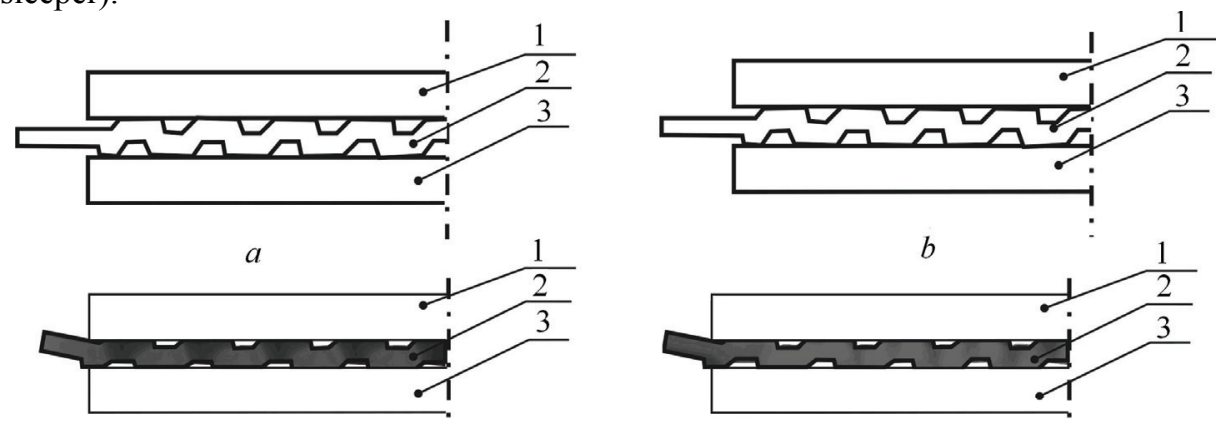

$U Y(\mathrm{~mm})$

$U X(\mathrm{~mm})$

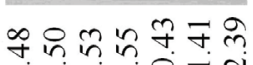

miño
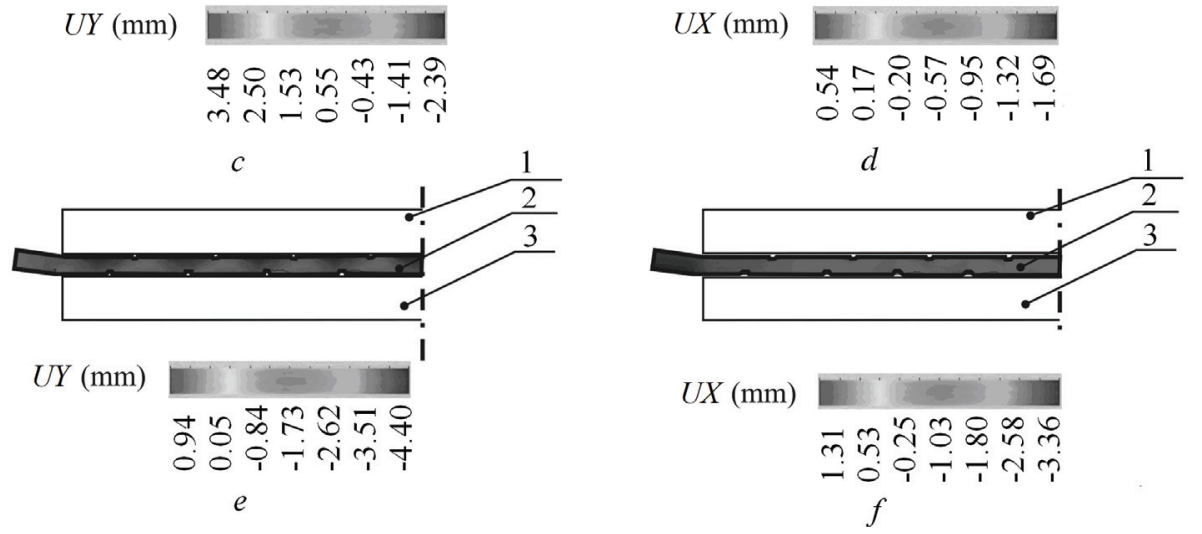

Fig. 3. Fields of absolute deformation distributions in vertical and horizontal planes relative to the symmetry axis of a trapezoidal pad: $c, e$-vertical fields of absolute deformation distributions; $d, f$-horizontal fields of absolute deformation distributions; $a, b-$ in terms of $0.0 \mathrm{kN}$ compression; $c, d$ - in terms of $100.0 \mathrm{kN}$ compression; $e f$ - in terms of $200.0 \mathrm{kN}$ compression; 1 - rail foot; 2 - elastomeric pad; 3 - metallic lining.

Figure 3 shows that the pad material is in a complex stress-strain state and friction forces between the interacting bodies within some contact zones (within some edge rows of riffles along the pad border) do not keep pad material from shearing. In terms of those zones, specific shearing forces are higher than the specific forces of shear resistance. Terminal pad sections are squeezed out from the gap between a rail foot and lining (sleeper).

Equivalent stresses $\sigma^{I V} \mathrm{MPa}$ have been analyzed according to the 4-th strength theory within the trapezoid pad due to the action of active compressing forces $F_{1}=100.0 \mathrm{kN}$ and $F_{2}=200.0 \mathrm{kN}$. It has been defined that the highest calculated stresses $\sigma^{I V}=26.0 \mathrm{MPa}$ are observed within the angular points of rail-lining (sleeper) contact both in terms of compressing forces $F_{1}=100.0 \mathrm{kN}$ and $F_{2}=200.0 \mathrm{kN}$.

The achieved stress $26.0 \mathrm{MPa}$ in terms of $F_{1}=100.0 \mathrm{kN}$ is retained during further loading growth up to $F_{2}=200.0 \mathrm{kN}$. In this context, redistribution of deformations and stresses into other pad areas takes place.

Table 1 represents results of quasistatic calculation of trapezoidal pad PRP-6 in terms of the action of vertical calculated load. 
Table 1. Results of quasistatic pad calculation in terms of the action of vertical calculated load.

\begin{tabular}{|c|c|c|c|c|c|}
\hline$\#$ & $F, \mathrm{kN}$ & $U Y, \mathrm{~mm}$ & $\sigma^{I V}, \mathrm{MPa}$ & $E, \mathrm{MPa}$ & $k, \mathrm{kN} / \mathrm{mm}$ \\
\hline 1 & 100 & 2.39 & 26.0 & 46.5 & 41.8 \\
\hline 2 & 200 & 4.40 & 26.0 & 26.4 & 49.8 \\
\hline
\end{tabular}

Apart from deformations, stresses, and modulus of elasticity, the table contains calculated stiffness of trapezoidal pad $k(\mathrm{kN} / \mathrm{mm})$. Since every stage of par loading involved solution of a linear problem, the stiffness was determined from expression:

$$
k_{i}=\frac{F_{i}-F_{i-1}}{Y_{i}-Y_{i-1}}
$$

where $F_{i}, F_{i-1}$ are forces acting within certain areas of loading; $Y_{i}, Y_{i-1}$ are deformations corresponding to certain areas of effecting loads.

Comparative analysis of stress-strain state of sinusoidal and trapezoidal pads shows that within the tops of sinusoidal riffles, deformability increases by $1.5-2.0 \mathrm{~mm}$, i.e. by 1.7 times [20] comparing to the riffles of a trapezoidal pad. In this context, compressing stresses within the riffles of a sinusoidal pad in upper and lower planes reach $\sigma_{z}=54.6 \mathrm{MPa}$ while compressing stresses within the tops and bodies of Trapezoidal pad riffles are $\sigma_{z}=26.0 \mathrm{MPa}$, i.e. by 2.1 times less.

The paper has considered problems of elastic rail seat pads having physical nonlinearity due to the use of elastomeric materials in the form of polyurethane, geometrical non-linearity as a result of the available variable geometrical parameters of riffles, and curvilinear regularity of pads deformability due to loading while constant changing of the area of contacting bodies and riffles geometry.

Stress-strain state of elastic elastomeric rail seat pads of intermediate rail fastening has been obtained with the use of finite element method and successive approximations method taking into account experimental studies.

It has been determined that the friction value between the contacting surfaces of elastic pad and adjacent products (rail foot and lining (or sleeper)) effects considerably the volumetric deformation and complex stress within a pad; moreover, terminal sections of a pad may the squeezed out from the gap between a rail foot and lining (sleeper).

FEM has been applied to evaluate stress-strain state of elastic clamps of various geometry and dimensions as well as real operating conditions of the intermediate rail fastening structure, distribution of external loads, fastening and deformation conditions, and mechanical characteristics of the material being used $[17,18]$.

While studying, displacements of unit points, stresses in finite elements, deformation and stress values as well as characteristics of clamp stiffness during the action of standard and operational loads were determined.

The research is based on the requirement that the force of rail foot pressing with one clamp should be equal to standard load of $12.5 \mathrm{kN}$ while values of the force of rail foot pressing with two clamps should be equal to $25.0 \mathrm{kN}$.

Figure 4 demonstrates elastic intermediate fastening of KPP-5 type being standard for the application in terms of Ukrainian railroads. The fastening uses elastic clamp KP-5. Structurally, elastic clamp of KP-5 type (1) is fixed within anchor head (2) concreted in a ferroconcrete sleeper. Anchor head has two grooves (open and closed ones). While mounting the clamps, one clamp end is put into the close groove while another clamp end is free. While assembling the fastening, free clamp end may slip along the cylindrical surface of the anchor head being mounted into another semi-open groove with the fixation of the required operating position. In terms of this mounting 
process, maximum relative transverse deformation of clamp ends is $16.5 \mathrm{~mm}$; clamp operates in a complex stress-strain state due to the effect of vertical forces upon the clamp tip $(12.5 \mathrm{kN})$ and transverse forces upon the clamp stem in terms of transverse deformation of $16.5 \mathrm{~mm}$.

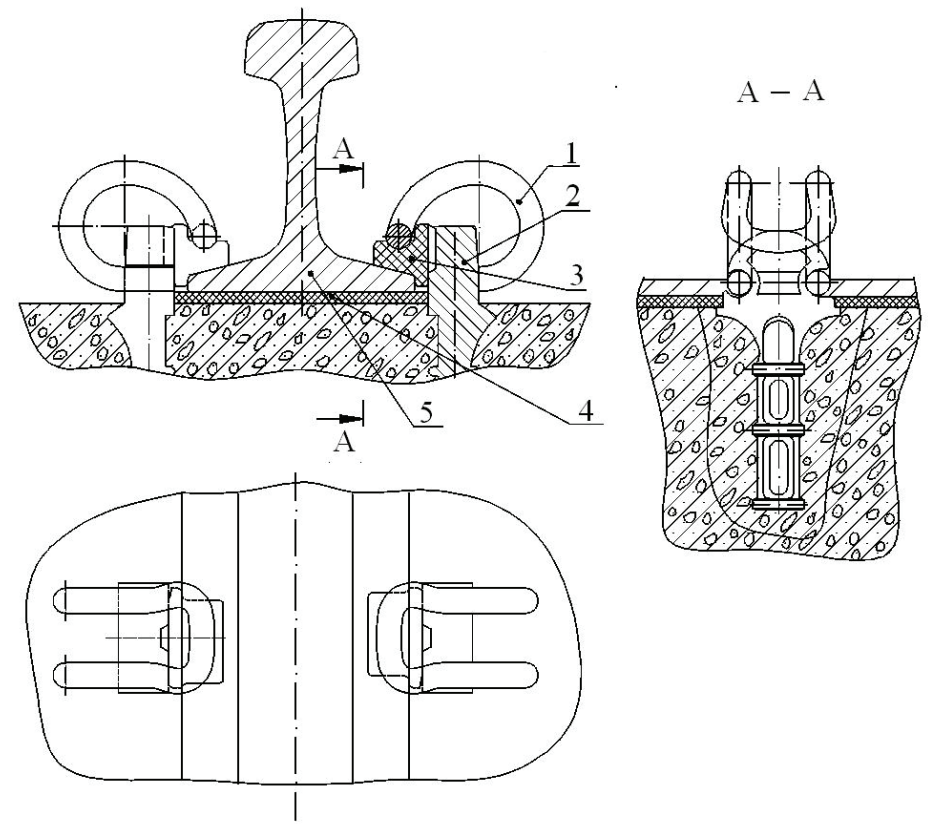

Fig. 4. Elastic intermediate fastening of KPP-5 type: 1 - elastic clamp of KP-5 type; 2 - anchor; 3 - insulating insert; 4 - rail seat lining; 5 - rail.

Loading and stress-strain state of KP-5 type clamp (Fig. 5, a) were determined according to the computational scheme represented in Figure $5, b$.

Figure 5 shows results of studies of loading and stress-strain state of KP-5 type clamp.

Studies were carried out for two modes of clamp operation: "working" mode (Fig. 5, $a, b, c, d, e$ ) and "mounting" mode, i.e. assembling-disassembling of the fastening (Fig. 5, $f, g, h, i$ ). In terms of "working" mode (Fig. 5, b), standard loading $R_{A Z}$ with the value of $12.5 \mathrm{kN}$ was applied to the contact point of the middle part of the clamp and rail foot; reactive loading $R_{B Z}$ and $R_{C Z}$ was formed on supports.

In terms of "mounting mode" (Fig. 5, $f$ ), clamp end free from fixation was stressed with $N_{A X}$ transverse loading providing process transversal displacement of free clamp end by the process value of $16.5 \mathrm{~mm}$.

Figure 5, $c$ shows the obtained values of clamp deformation in a "working" mode where vertical displacements of $Z$ point of clamp tip and rail foot are $Z=6.15 \mathrm{~mm}$ (in terms of $12.5 \mathrm{kN}$ loading) and displacements directed from the rail axis are $X=-2.5 \mathrm{~mm}$, $Y=2.36 \mathrm{~mm}$.

Figure 5, $d$, e represents equivalent stresses in a "working" mode being $1557 \mathrm{MPa}$.

Figure 5, $g$ illustrates transverse clamp deformations in a "mounting" mode where process transversal displacements are specified by $16.5 \mathrm{~mm}$ value or $8.25 \mathrm{~mm}$ for each side of the clamp end section.

Figure 5, h, $i$ show fields of equivalent stresses in a "mounting" mode. Maximum stresses in a "mounting" mode are equal to $1340 \mathrm{MPa}$. Value of transverse loading on the clamp stem is equal to $6.63 \mathrm{kN}$. 


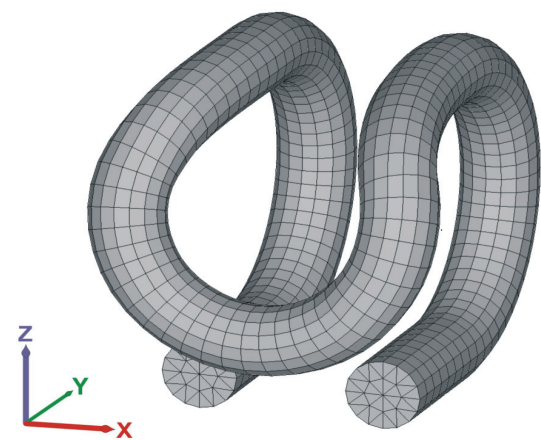

$a$

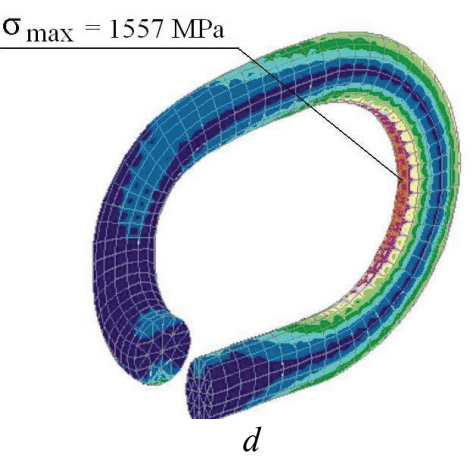

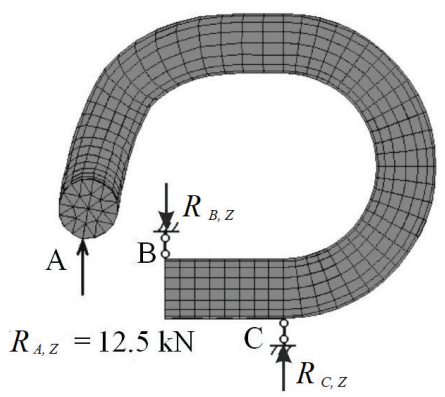

$b$

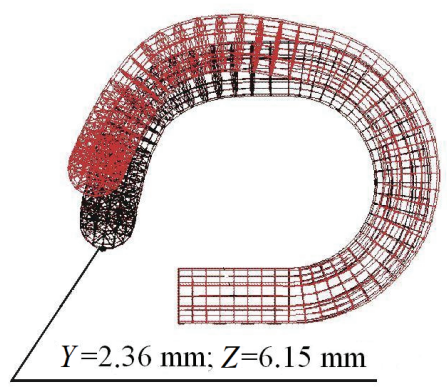

$c$

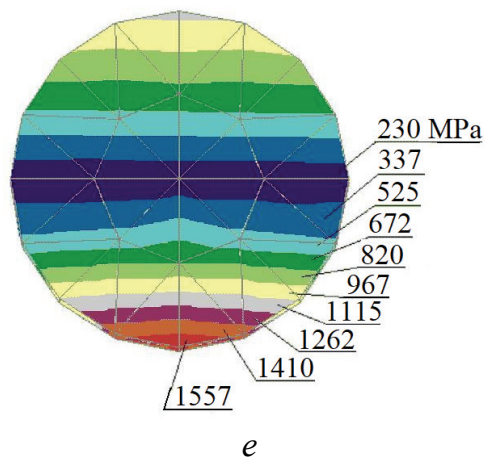

Fig. 5,a,b,c,d,e. Stress-strain state of elastic KP-5 type clamp in a "working" mode (beginning of the figure ): $a$-general clamp view, $b$ - computational scheme for a clamp, $c$ - clamp deformation, $d-$ fields of equivalent stresses $\sigma^{\mathrm{IV}}, e$ - highest equivalent stresses within the weakest section.

According to the results of the ratio of loads and deformations, corresponding vertical $2.03 \mathrm{kN} / \mathrm{mm}$ and transversal $0.4 \mathrm{kN} / \mathrm{mm}$ clamp stiffness has been defined.

Table 2 represents general characteristics of stress-strain state of elastic clamps.

Elastic clamps of KP-1 and KP-5 types differ structurally only in the available spherical widening within the zone of clamp tip of KP-5 type instead of radial transversal bending within the clamp of KP-1 type. Equivalent stresses in a "working" mode of operation for clamps of KP-1 and KP-5 type are $1580.0 \mathrm{MPa}$ and $1557.0 \mathrm{MPa}$ respectively in terms of the admissible stresses for the used steel being $\left[\sigma_{0.2}\right]=1570.0 \mathrm{MPa}$ and $\left[\sigma_{r}\right]=1710.0 \mathrm{MPa}$.

The research results prove better efficiency of KP-5 type clamps in terms of operating mode comparing to KP-1 type ones. 
Table 2. Characteristics of stress-strain state of elastic clamps.

\begin{tabular}{|c|c|c|c|c|c|c|}
\hline \multirow[t]{2}{*}{ \# } & \multirow[t]{2}{*}{ Clamp type } & \multirow[t]{2}{*}{$\begin{array}{c}\text { Maximum } \\
\text { equivalent } \\
\text { stresses } \sigma^{\mathrm{IV}} \text {, } \\
(\mathrm{MPa})\end{array}$} & \multicolumn{3}{|c|}{$\begin{array}{c}\text { Maximum clamp } \\
\text { displacements within its } \\
\text { contact point with rail foot } \\
\text { along the coordinate axes, } \\
\text { mm }\end{array}$} & \multirow[t]{2}{*}{$\begin{array}{c}\text { Clamp } \\
\text { stiffness } \\
\text { within its } \\
\text { contact point } \\
\text { with rail foot, } \\
\mathrm{kN} / \mathrm{mm}\end{array}$} \\
\hline & & & $X$ & $\mathrm{Y}$ & $\mathrm{Z}$ & \\
\hline \multirow[t]{2}{*}{1.} & $\begin{array}{l}\text { KP-1, } \\
\text { "working } \\
\text { mode" }\end{array}$ & 1580 & 0 & -2.5 & 6.41 & 1.95 \\
\hline & $\begin{array}{c}\text { KP-1, } \\
\text { "mounting } \\
\text { mode" }\end{array}$ & 1450 & - & - & - & $\begin{array}{c}\text { transverse } \\
\text { stiffness } \\
0.45\end{array}$ \\
\hline \multirow[t]{2}{*}{2.} & $\begin{array}{l}\text { KP-5, } \\
\text { "working } \\
\text { mode", }\end{array}$ & 1557 & 0 & -2.36 & 6.15 & 2.03 \\
\hline & $\begin{array}{c}\text { KP-5, } \\
\text { "mounting } \\
\text { mode" }\end{array}$ & 1340 & - & - & - & $\begin{array}{c}\text { transverse } \\
\text { stiffness } \\
0.4\end{array}$ \\
\hline \multirow[t]{2}{*}{3.} & $\begin{array}{l}\text { KPT-7, } \\
\text { "working } \\
\text { mode" }\end{array}$ & 2239 & 0 & -3.2 & 14.4 & 0.868 \\
\hline & $\begin{array}{c}\text { KPT-7, } \\
\text { "mounting } \\
\text { mode" }\end{array}$ & 2705 & 0 & -3.9 & 17.4 & 0.868 \\
\hline \multirow[t]{3}{*}{4.} & $\begin{array}{l}\text { KP-A1 } \\
\text { "working } \\
\text { mode" }\end{array}$ & 1721 & 0 & -1.14 & 13.2 & 0.947 \\
\hline & $\begin{array}{c}\text { KP-A1 } \\
\text { "assembling } \\
\text { mode" }\end{array}$ & 2113 & 0 & -1.40 & 15.0 & 1.033 \\
\hline & $\begin{array}{c}\text { KP-A1 } \\
\text { "disassembling } \\
\text { mode" }\end{array}$ & 2130 & 0 & -1.00 & 15.9 & 0.975 \\
\hline
\end{tabular}

In the context of process "mounting" mode with the widening of end sections of clamps by $16.5 \mathrm{~mm}$, clamps of KP-5 type are less stresses comparing to the stress in KP-1 type clamps due to the fact that the middle share of the clamps tip is of spherical geometry.

Stress-strain state of elastic clamp of KP-A1 type was determined for three operating modes: working mode (Fig. 6), mode of fastening unit assembling (Fig. 7), and mode of fastener unit disassembling.

Figure $6 a, b, c, d, e, f$ shows material of the research of stress-strain state of elastic KP-A1 type clamp in a "working" mode of operation. Figure 6, $a$ represents general view of a clamp with a mesh. Studies were carried out according to a computational scheme given in Figure 6, $a$. Arrangement of the clamp end sections within the gaps of anchor head is modeled by two conventional supports mounted within the conventional staying points of the clamp end sections within the areas of anchor head gaps.

Clamp was stresses under operating condition by standard loading $P_{\text {calc }}=12.5 \mathrm{kN}$ applied in the middle share of the clamp tip where there is a clamp-rail foot contact by means of insulating insert. Distance between the conventional supports within the anchor head gaps varied from $20 \mathrm{~mm}$ up to the whole length of possible contact. 


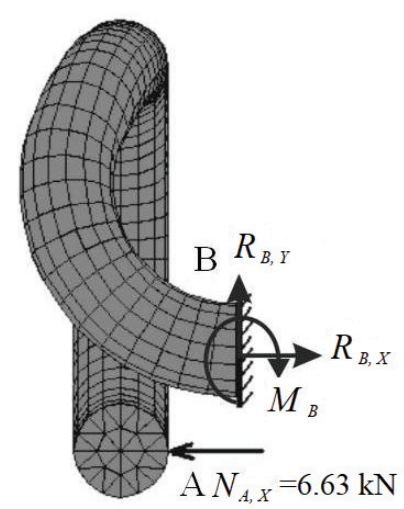

$f$

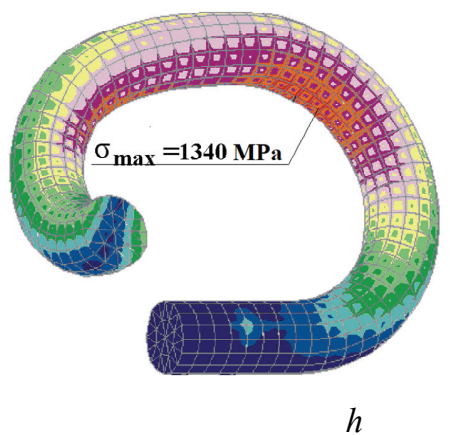

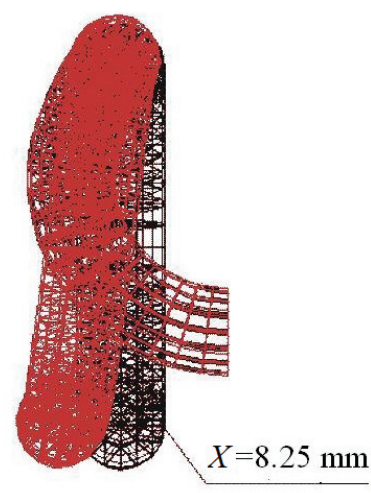

$g$

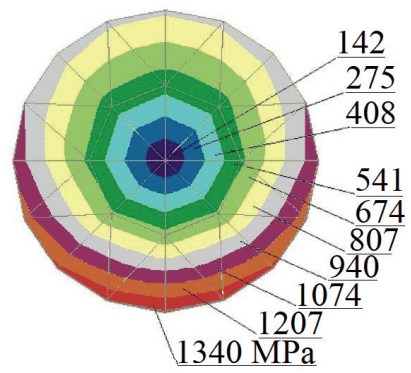

$i$

Fig. $\mathbf{5}, \boldsymbol{f}, \boldsymbol{g}, \boldsymbol{h}, \boldsymbol{i}$. Stress and strain state of elastic KP-5 type clamp in a "mounting" mode (ending of the Figure): $f$ - computational scheme for a clamp, $g$ - clamp deformation, $h$ - fields of equivalent stresses $\sigma^{\mathrm{IV}}, i$ - highest equivalent stresses within the weakest section.

Figure $6, c, d$ shows equivalent stresses in a clamp due to the effect of calculated loading. It has been determined that the highest equivalent stresses in a clamp are 1721.0 $\mathrm{MPa}$. The highest calculated deformation of the middle part of the clamp tip within a vertical plane is $13.2 \mathrm{~mm}$ (Fig. $6, f)$.

Figure 7, $a, b, c, d, e, f$ represents some results of the study of stress-strain state of elastic KP-A1 type clamp in the mode of fastening unit assembling. Figure 7, $a$ shows general view of a clamp with the mesh. Studies were carried out according to the computational scheme represented in Figure 7, $b$.

Arrangement of the clamp end sections within the gaps of anchor head is modeled by several variants of staying of the clamp end section within the anchor head gaps. Clamp was stresses under conditions of fastener unit assembling by vertical loading applied to the middle part of the clamp tip. Value of vertical loading $P_{\text {calc }}$ was $15.5 \mathrm{kN}$ since standard vertical loading of $12.5 \mathrm{kN}$ was complemented with $3.0 \mathrm{kN}$ loading generated from the additional clamp deformation by $3.0 \mathrm{~mm}$. Moreover, additional calculated loading $N_{2}=10.8 \mathrm{kN}$ from the operating stop block of the device, while clamp moving along the inclined plane of the anchor head and insert head up to the clamp tip fixation within the insert low, is taken into account. Besides, calculated loading $N_{3}=2.34 \mathrm{kN}$ is taken into consideration; the loading is formed due to the resistance to the clamp end sections displacement within the anchor head gaps while assembling intermediate rail fastening. 

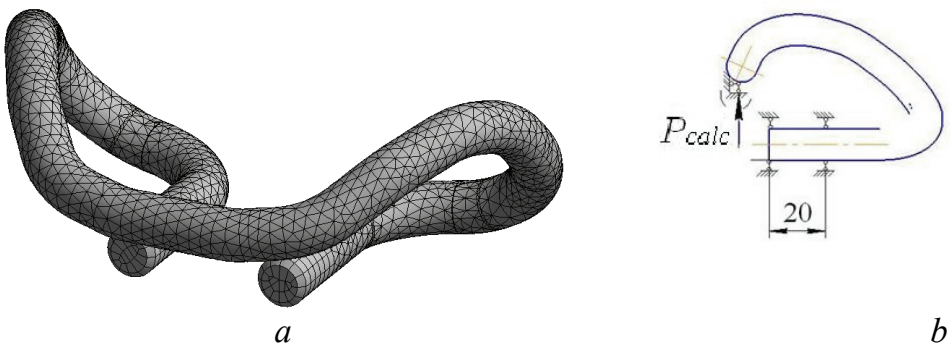

$$
P_{\text {calc }}=12.5 \mathrm{kN}
$$

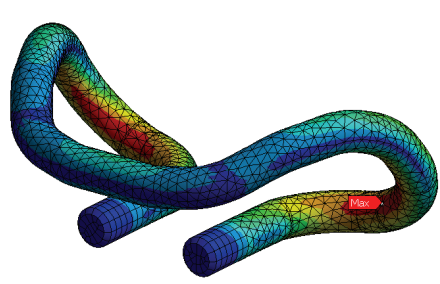

$c$

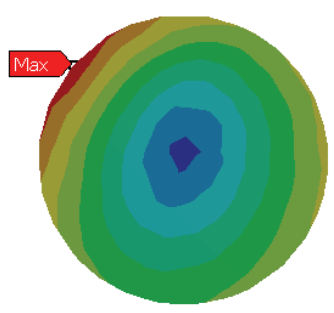

$e$
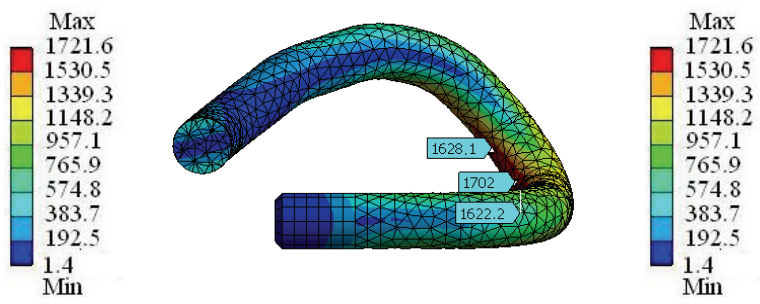

$d$
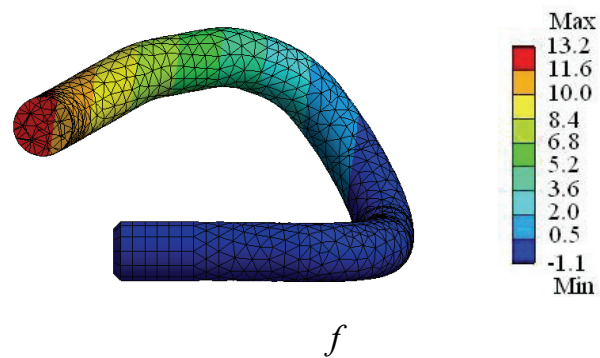

Fig. 6. Stress-strain state of elastic KP-A1 type clamp in a "working" mode: $a$ - general clamp view; $b$ - computational scheme for a clamp; $c$ and $d$ - fields of equivalent stresses $\sigma^{\mathrm{IV}}$ (general view, side view); $e$ - highest equivalent stresses within the weakest section; $f$ - fields of clamp displacement.

Figure $7, c, d$ shows equivalent stresses in a clamp due to the effecting system of loads $P_{\text {calc }}, N_{2}, N_{3}$ in terms of assembling of intermediate rail fastening unit. It has been specified that the highest equivalent stresses within a clamp are 2113.0 MPa. The highest calculated deformation of the middle share of the clamp nip within a vertical plane is $14.97 \mathrm{~mm}$ (Fig. 7, f).

Comparative analysis of the equivalent maximum stresses within the developed clamps of KP-A1 type and their analogues, clamps of KPT-7 type, demonstrates that stress-strain state of KP-A1 type clamps is by 1.28-1.30 times higher comparing to the clamps of KPT-7 type. As for clamps of KP-A1 type, their stiffness within the contact point with the rail foot is by 1.19 times less comparing to the clamps of KPT-7 type. Better stress-strain state indices in terms of KP-A1 type clamps, comparing to the ones of KPT-7 type, is connected with the fact that KP-A1 type clamps are of forked geometry developing higher deformability and torsional stresses along with the bending ones.

Steel material $\left[\sigma_{r}\right]=2240.0 \mathrm{MPa}$ is recommended to provide performability of KP-A1 type clamps under development while clamps of KPT-7 type are produced using $\left[\sigma_{r}\right]=2030.0 \mathrm{MPa}$ steel material. 

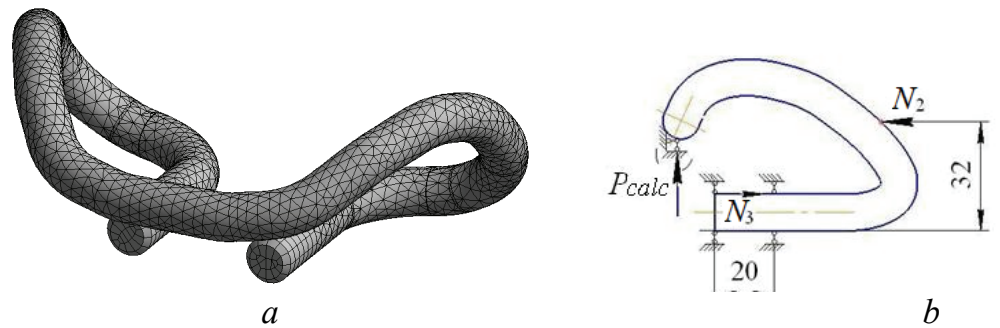

$$
P_{\text {calc. }}=15.5 \mathrm{kN}
$$

$N_{2}=10.85 \mathrm{kN}$

$N_{3}=2.34 \mathrm{kN}$
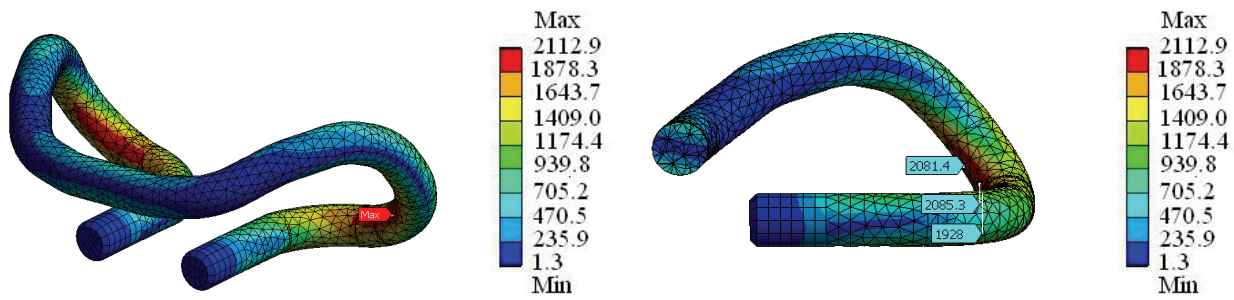

C
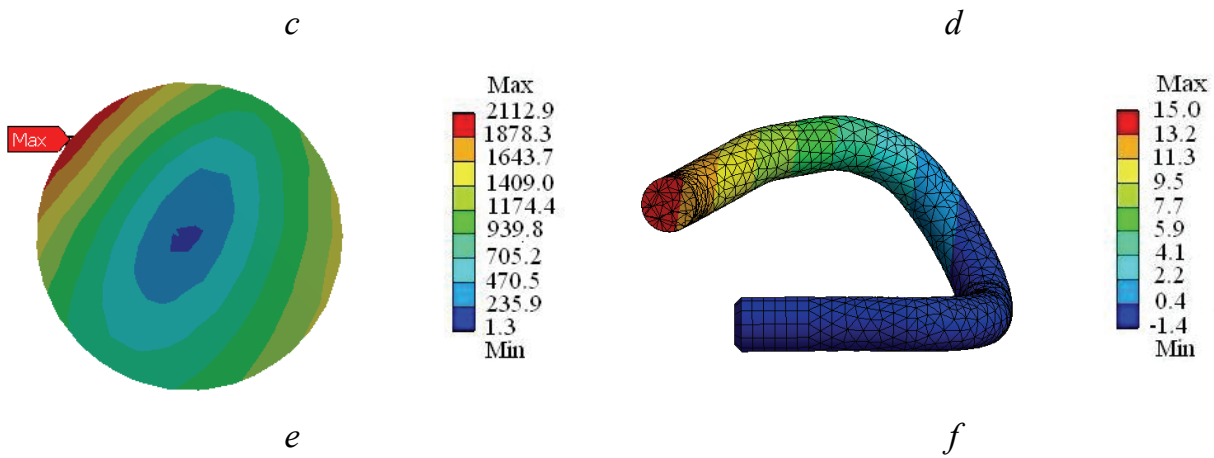

$e$

$f$

Fig. 7. Stress-strain state of elastic KP-A1 type clamp in a "mounting" mode of assembling: $a$ - general clamp view; $b$ - computational scheme for a clamp; $c$ and $d$ - fields of equivalent stresses $\sigma^{\mathrm{IV}}$ (general view, side view); $e$ - highest equivalent stresses within the weakest section; $f$ - fields of clamp displacement.

\section{Conclusions}

1. Stress-strain state of elastic elastomeric rail seat pads of intermediate rail fastening of new type and series pads of series fastening of KPP-5 type has been analyzed involving finite element method and successive approximations method along with the use of finite element method.

It has been determined that, comparing to series pads with sinusoidal riffles geometry, the developed elastic pads with trapezoidal riffles are characterized by deformability being by 1.7 times less; their rational stiffness is $37-40 \mathrm{kN} / \mathrm{mm}$.

Compressing stresses within the tops of trapezoidal-riffle pads being developed are equal to $26.0 \mathrm{MPa}$ while compressing stresses within the tops of series pads with sinusoidal riffles are equal to $54.6 \mathrm{MPa}$ being by 2.1 times less.

That proves the advantage of the pads being developed comparing to the series products.

2. Stress-strain state of elastic clamps of KP-A1 type of the developed intermediate rail fastening and their clamp analogues of KP-1, KP-5, and KPT-7 types as well as clamps of KPP-1, KPP-5, and KPPT-7 types has been examined by means of finite element method. 
It has been defined that stresses state of elastic clamps of KP-A1 type of fastening being developed is better by $1.28-1.3$ times and their deformed state is by 1.19 times better comparing to analogue KPT-7 clamps of test fastening of KPPT-7 type.

The studies confirm the expediency of the proposed engineering solutions as for the design of rail seat pads and elastic clamps of the developed intermediate rail fastening.

3 . Innovative system of intermediate rail fastening is aimed for curved sections of mainline railways with $200-600 \mathrm{~m}$ radius, industrial rail transport with $80-600 \mathrm{~m}$ radius of curvature, and underground rail transport with 900, 750, and $600 \mathrm{~mm}$ gauge width and 8-20 m radius of curvature as well as straight-line route sections of railway and industrial and underground rail transport.

4. Results of the studies concerning the development of innovative intermediate rail fastening are used to design railroads which may operate under complicated conditions of Ukrainian main routes for traffic flows of about 1.2 bln. $t$ of total handled freight; train velocities up to $300 \mathrm{~km} / \mathrm{hr}$; and for curved track sections under complex operating conditions of Lviv railroad within the mountain pass areas with track inclination up to $30 \%$ and curvature radii up to $200 \mathrm{~m}$.

In the long term, the research results will be used for railroads of open-pits of Kryvyi Rih mining-and-processing integrated works (where curvature radii are more than $80 \mathrm{~m}$ and longitudinal route inclination is up to $60 \%$ ) for locomotive units with great axial loading of $400-600 \mathrm{kN}$ as well as mine railroads with 900,750 , and $600 \mathrm{~mm}$ gauge and curvature radii of $8-20 \mathrm{~m}$.

\section{References}

1. Yermakov, V.M. (2009). Skrepleniya dlya zhelezobetonnykh shpal: trebovaniya, obosnovaniya, otsenka. Nauchno-populyarnyy, proizvodstvenno-tekhnicheskiy zhurnal "Put i putevoe hozyaystvo", 1, 10-14

2. Kruglov, V.M., Aksenov, Yu.N., Bogachev, A.Yu., Kuzina, Ye.G. (2011). Modernizirovannoe relsovoe skreplenie ARS. Nauchno-populyarnyy, proizvodstvennotekhnicheskiy zhurnal "Put i putevoe hozyaystvo", 11, 10-12

3. Yermakov, V.M. (2013). Nauchnaya konferentsiya po verkhnemu stroeniyu puti v g. Darmshtadt. Nauchno-populyarnyy, proizvodstvenno-tekhnicheskiy zhurnal "Put $i$ putevoe hozyaystvo", 1, 31-33

4. Filatov, Ye.V., Kovenkin, D.A., Kupko, R.S. (2013). Ekspluatatsionnye ispytaniya skrepleniya ARS-4 na Vostochno-Sibirskoy doroge. Nauchno-populyarnyy, proizvodstvenno-tekhnicheskiy zhurnal "Put i putevoe hozyaystvo", 1, 16-33

5. Hovorukha, V.V. (2005). Mekhanika deformirovaniya $i$ razrusheniya uprugikh elementov promezhutochnykh relsovykh skrepleniy. Dnepropetrovsk: Izd-vo Lira LTD

6. Karpushchenko, N.I., Antonov, N.I. (2003). Sovershenstvovanie relsovykh skrepleniy. Novosibirsk: Izd-vo SGUPSa

7. Kostiuk, M.D., Kozak, V.V., Yakovliev, V.O. (2010). Budivnytstvo ta rekonstruktsiia zaliznychnoi merezhi Ukrainy dlia zbilshennia propusknoi spromozhnosti ta zaprovadzhennia shvydkisnoho rukhu poizdiv. Kyiv: E.O. Paton Electric Welding Institute

8. Lysiuk, V.S., Sazonov, V.N., Bashkatova, L.V. (2003). Prochnyy $i$ nadezhnyy zheleznodorozhnyy put. Mooskva: PBTC "Akademkniga”

9. Danilenko, Ye.I., Kostiuk, M.D., Zhuchenko, O.M. (2002). Suchasni reikovi pruzhni skriplennia i osoblyvosti vymoh do vitchyznianykh skriplen na zalizobetonnykh shpalakh. Zaliznychnyi transport Ukrainy, 6, 3-12

10. Hovorukha, V.V. (2013). Sovershenstvovanie relsovogo puti i strelochnykh perevodov podzemnogo relsovogo transporta. Coal of Ukraine, 3, 44-49 
11. Darenskyi, O.M. (2011). Teoretychni ta eksperymentalni doslidzhennia roboty zaliznychnykh kolii promyslovoho transportu. Kharkiv: UkrDAZT

12. Hovorukha, V.V. (2008). Prystrii dlia ankernoho reikovoho skriplennia iz zalizobetonnoiu osnovoiu Patent No 17433, Ukraine

13. Hovorukha, V.V. (2008). Anker zakladnyi promizhnoho pruzhnoho reykovoho skriplennia. Patent No 17117, Ukraine

14. Hovorukha, V.V. (2008). Klema pruzhna promizhnoho reykovoho skriplennia. Patent No 17118 , Ukraine

15. Hovorukha, V.V. (2008). Prokladka pidreykova. Patent No 17119, Ukraine

16. Hovorukha, V.V. (2008). Shpala zalizobetonna promizhnoho reykovoho skriplennia. Patent No 17120, Ukraine

17. Gallager, R. (1984). Metod konechnykh elementov. Basics. Mooskva: Mir

18. Zenkevich, O. K. (1975). Metod konechnykh elementov v tekhnike. Mooskva: Mir

19. Hovorukha, V.V. (2002). Prokladka. Patent No 49767 A, Ukraine

20. Hovorukha, V.V. (2010). Metod opredeleniya ratsionalnykh parametrov elastomernykh podrelsovykh prokladok dlya promezhutochnykh relsovykh skrepleniy. Geo-Technical mechanics, 88, 219-234 